\title{
Growth Suppression by Exogenous Abscisic Acid and Uniconazole for Prolonged Marketability of Tomato Transplants in Commercial Conditions
}

\author{
Shinsuke Agehara \\ Gulf Coast Research and Education Center, University of Florida, 14625 \\ County Road 672, Wimauma, FL 33598
}

\author{
Daniel I. Leskovar ${ }^{1}$ \\ Department of Horticultural Sciences, Vegetable and Fruit Improvement \\ Center, Texas A\&M AgriLife Research, Texas A\&M University, 1619 Garner \\ Field Road, Uvalde, TX 78801
}

Additional index words. chlorosis, growth retardant, height control, plant hormone, S-ABA, Solanum lycopersicum

\begin{abstract}
Vegetable transplants grown in commercial high-density trays can quickly outgrow the optimal size for shipping and transplanting, limiting transplant performance, and marketing flexibility for commercial nurseries. Abscisic acid (ABA) and uniconazole can suppress shoot growth by inducing stress-adaptive responses and inhibiting gibberellin synthesis, respectively. We evaluated the effectiveness of the two growth regulators in prolonging marketability of 'Florida 91' and 'Mariana' tomato (Solanum lycopersicum L.) transplants at commercial nursery greenhouses in Texas and Florida. Spray treatments in the Texas experiment were 0 and $3.8 \mathrm{~mm} \mathrm{ABA}$ at 7, 5, 3, or 1 days before maturity (DBM), and those in the Florida experiment were no spray control, $3.8 \mathrm{~mm} A B A$ at $7,5,3$, or 1 DBM, and $34 \mu \mathrm{M}$ uniconazole at 4 DBM. Both ABA and uniconazole showed minimal cultivar-specific effects. Different growth modifications were induced by ABA and uniconazole. First, suppression of stem elongation by ABA was reversible by 7 days after maturity (DAM), whereas that by uniconazole lasted for 20 days or until 16 DAM with up to $15 \%$ suppression in stem elongation. Second, only ABA inhibited leaf expansion and shoot dry matter accumulation. The primary growthmodulating effect of uniconazole was limited to height control, which is beneficial for producing compact transplants, rather than as a growth holding strategy. By contrast, the overall growth suppression by ABA is desirable for prolonging transplant marketability. Importantly, the magnitude of this growth suppression was moderate (up to $22 \%$ shoot biomass reduction at $8 \mathrm{DAM}$ ) and transient, followed by a rapid recovery. Furthermore, ABA caused relatively smaller inhibition in root growth, allowing sufficient root development and increasing the root-to-shoot ratio at 0 to 8 DAM. The growth suppression by ABA was maximal when it was applied at 7 to $5 \mathrm{DBM}$, indicating the age-dependent sensitivity of tomato seedlings to exogenous ABA. Although leaf chlorosis was induced by $A B A$ in a similar age-dependent manner, it was transient and reversible by 7 DAM. These results suggest that $A B A$ application 7 to $5 \mathrm{DBM}$ is an effective growth holding strategy for tomato transplants.
\end{abstract}

Vegetable transplants grown for commercial producers need an ideal size to minimize damage during shipping and transplanting operations and to enable successful establishment in the field (Agehara and Leskovar, 2015).

\footnotetext{
Received for publication 25 Oct. 2016. Accepted for publication 15 Jan. 2017.

This work was supported by Valent BioSciences Corporation and National Institute of Food and Agriculture, U.S. Department of Agriculture under Agreement no. 2008-34461-19061, "Rio Grande Basin Initiative." We thank Juan Esquivel, Juan Gonzalez, and Melina Gonzalez for technical assistance and Speedling Inc. for providing plant materials.

${ }^{1}$ Corresponding author. E-mail: d-leskovar@tamu. edu.
}

However, vegetable transplants can quickly outgrow the optimal size, limiting the marketing flexibility for commercial producers. Overmature transplants generally have spindly stems and excessive leaf growth, whereas their root growth is limited because of the small rooting volume of high-density plug trays (Marr and Jirak, 1990; Nishizawa and Saito, 1998). Such transplants are susceptible not only to damage during shipping and transplanting (Garner and Björkman, 1996; Shaw, 1993), but also to wind lodging in the field (Garner and Björkman, 1999; Latimer and Mitchell, 1988). In addition, the imbalance between transpiration demand and water uptake capacity can result in severe transplant shock and poor stand establishment (Agehara and Leskovar, 2012).

Uniconazole is a plant growth retardant used in commercial ornamental plug production to improve plant compactness, marketable value, and shelf life (Currey and Lopez, 2010). The mode of action involves inhibition of gibberellin biosynthesis, which in turn, limits stem elongation and overall shoot growth (Rademacher, 2000), and its effectiveness is well documented in many ornamental species (Blanchard and Runkle, 2007; Currey et al., 2012; Gibson and Whipker, 2001, 2003). Recently, uniconazole was registered as Sumagic (Valent BioSciences, Libertyville, IL) and became available also for vegetable crops, including pepper (Capsicum annuum L.), tomato, and eggplant (Solanum melongena L.). According to the product label, Sumagic is recommended primarily for height control and must be applied during early development, no later than $14 \mathrm{~d}$ after two to four true leaf stage.

ABA is a plant hormone, which biosynthesis increases under water stress to induce adaptive stress responses (Davies and Jones, 1991). The immediate physiological response is stomatal closure, which in turn inhibits photosynthesis and transpiration-driven mass flow of nutrients (Taiz and Zeiger, 2010; Umezawa, 2011), whereas the morphological response is inhibition of leaf expansion (Bacon et al., 1998; Van Volkenburgh, 1999). Thus, the overall effect of ABA is shoot growth suppression and an increase in root-to-shoot ratio. The potential of $\mathrm{ABA}$ as a growth retardant has been studied for some vegetable transplants. For example, cucumber (Cucumis sativus L.) and tomato seedlings sprayed with 0.38 or $1.89 \mathrm{~mm}$ ABA had reduced transpirational water loss and stem elongation during dark storage, thereby maintaining the overall quality and optimal size for transplanting (Yamazaki et al., 1995). In bell pepper, Leskovar and Cantliffe (1992) reported that the concentration effect of ABA on stem elongation was quadratic, with height suppression occurring above $10 \mu \mathrm{m}$. The efficacy of ABA is mostly age dependent, and growth suppression is normally maximized when ABA is applied at the cotyledon stage (Agehara and Leskovar, 2014a, 2014b; Biai et al., 2011).

In our previous study, we used bell pepper seedlings to test the growth holding effects of $3.8 \mathrm{~mm}$ ABA and $34 \mu \mathrm{m}$ uniconazole applied shortly before the anticipated maturity stage (Agehara and Leskovar, 2015). Our results suggested that the transient overall growth suppression by ABA is effective in prolonging marketability of bell pepper transplants. Tomato is a high-value crop, which is established in the field mostly by containerized transplants. In general, tomato seedlings grow faster than pepper seedlings, so the need for an effective growth holding strategy is greater in this species. The objective of this study was to examine the magnitude, duration, and reversibility of growth suppression by $\mathrm{ABA}$ and uniconazole in tomato seedlings.

\section{Materials and Methods}

Plant material and growth conditions. Two experiments were conducted at commercial 
nursery (Speedling Inc., Ruskin, FL) greenhouses located in Alamo, TX (Expt. 1) and Ruskin, FL (Expt. 2) from Aug. to Oct. 2009. At each location, seeds of two tomato cultivars, 'Florida 91' (Seminis Vegetable Seeds, St. Louis, MO) and 'Mariana' (Sakata Seed America, Morgan Hill, CA), were sown in a polystyrene tray with 128 inverted pyramid cells, each containing $35 \mathrm{~mL}$ of peat-lite mix (Speedling Peat-lite; Speedling Inc.). Seedlings were grown following commercial transplant production practices in each location.

Treatments. In Expt. 1 (Texas location), treatments were factorial combinations of two ABA concentrations [0 and $3.8 \mathrm{~mm}$ $\left.\left(1000 \mathrm{mg} \cdot \mathrm{L}^{-1}\right)\right]$ and four application timings (7, 5, 3, and 1 DBM). In Expt. 2 (Florida location), there were six treatments: no spray control, four application timings of $3.8 \mathrm{~mm}$ $\operatorname{ABA}(7,5,3$, and $1 \mathrm{DBM})$, and one treatment of $34 \mu \mathrm{M}\left(10 \mathrm{mg} \cdot \mathrm{L}^{-1}\right)$ uniconazole applied at 4 DBM. The maturity date was considered when seedlings were anticipated to reach the optimal size for shipping and transplanting according to the commercial nursery.

The formulation of ABA stock solution was VBC-30151 (Valent BioSciences) containing $10 \%$ of S-ABA, a naturally occurring active form in plants. Uniconazole was formulated as Sumagic. Test solutions were prepared immediately before each treatment by diluting the stock solutions with irrigation water at the nursery. All test solutions including the control were mixed with a nonionic surfactant (CapSil; Aquatrols, Paulsboro, NJ) at $0.05 \%(\mathrm{v} / \mathrm{v})$, which showed no significant effect on transplant growth in our preliminary experiment.

A $\mathrm{CO}_{2}$-pressurized backpack sprayer (Model T; Bellspray, Opelousas, LA) was used to spray the test solutions evenly over the seedlings between 10:00 and 11:00 AM. The sprayer was equipped with three flat-fan nozzles (TP8002VS; TeeJet Technologies,
Wheaton, IL) and $\mathrm{CO}_{2}$ cylinder with pressure maintained at $276 \mathrm{kPa}$. Spray volume was 0.61 $\mathrm{L} \cdot \mathrm{m}^{-2}(0.71 \mathrm{~mL} / \mathrm{plant})$, which wetted the leaves thoroughly to the dripping point. The spray concentration and volume were determined based on manufacturer recommendations.

Transplant growth measurements. In Expt. 1 , stem height, cotyledon number, and leaf chlorophyll index were measured nondestructively at $8,6,4,2$, and 0 DBM and 7 and 14 DAM, whereas shoot and root dry weight were measured destructively at 8 and 0 DBM and 7 and 14 DAM, respectively. Five plants per replication were randomly selected before the first measurement. All nondestructive measurements were made repeatedly on the selected plants between 0800 and 1000 HR on each measurement day. Stem height $(\mathrm{cm})$ was measured from the medium surface to the shoot apex. Relative stem elongation rate $\left(\mathrm{RSER}, \mathrm{mm} \cdot \mathrm{cm}^{-1} \cdot \mathrm{d}^{-1}\right.$ ) was calculated as follows:

$$
\mathrm{RSER}=\frac{\left(\ln H_{2}-\ln H_{1}\right)}{\left(t_{2}-t_{1}\right)} \times 10
$$

where $\ln H_{1}$ and $\ln H_{2}$ are the natural logarithm of stem height at time one, $t_{1}$, and time two, $t_{2}$, respectively.

Leaf chlorophyll index was measured using a chlorophyll meter (SPAD-502; Konica Minolta Sensing, Tokyo, Japan) on the youngest fully open leaf and the largest leaf. Two readings were taken per leaf on a leaf lamina between major leaf veins. At each measurement time, three plants per replication (tray) were randomly sampled and washed to remove the growth medium. Shoots and roots were separated and dried at $65^{\circ} \mathrm{C}$ for $72 \mathrm{~h}$ to determine dry weight.

In Expt. 2, stem height was measured nondestructively at $8,6,4,2$, and 0 DBM and 8, 16, and 29 DAM, whereas shoot and root dry weight were measured destructively at 8 and 0 DBM and 8 and 16 DAM, respectively. These measurements were made using the methods described for Expt. 1.

Statistical design and analysis. In Expt. 1, there were four replicates for each treatment arranged in a split-plot design with application timing as the main plot and $\mathrm{ABA}$ concentration as the subplot. One half of each seedling tray was sprayed with the control solution, whereas the other half was sprayed with $3.8 \mathrm{~mm}$ ABA solution. In Expt. 2 , there were four replicates for each treatment arranged in a split-plot design with cultivar as the main plot and spray treatment as the subplot. Each spray treatment was assigned randomly to an individual tray.

All data analyses were run in SAS (version 9.2; SAS Institute, Cary, NC), and $P$ values less than 0.05 were considered statistically significant. In both experiments, treatment effects were tested using the restricted maximum likelihood method with the DDFM $=\mathrm{KR}$ option in the MIXED procedure. Pretreatment data were included as covariates. Multiple comparisons of least squares means were performed by the Tukey-Kramer test in the MIXED procedure. When heteroscedasticity was indicated by a likelihood ratio test, the MIXED procedure was run with the GROUP option in the REPEATED statement.

In Expt. 2, two specific hypotheses were also tested by orthogonal contrasts in the MIXED procedure. First, we hypothesized that all ABA treatments have equivalent growth modulating effects, thereby comparing the control with the pooled ABA treatments. Second, we hypothesized that growth modulation by $\mathrm{ABA}$ is different from that by uniconazole, thereby comparing the pooled ABA treatments with the uniconazole treatment.

\section{Results}

ABA effects (Expt. 1). Stem elongation in the control remained relatively constant until

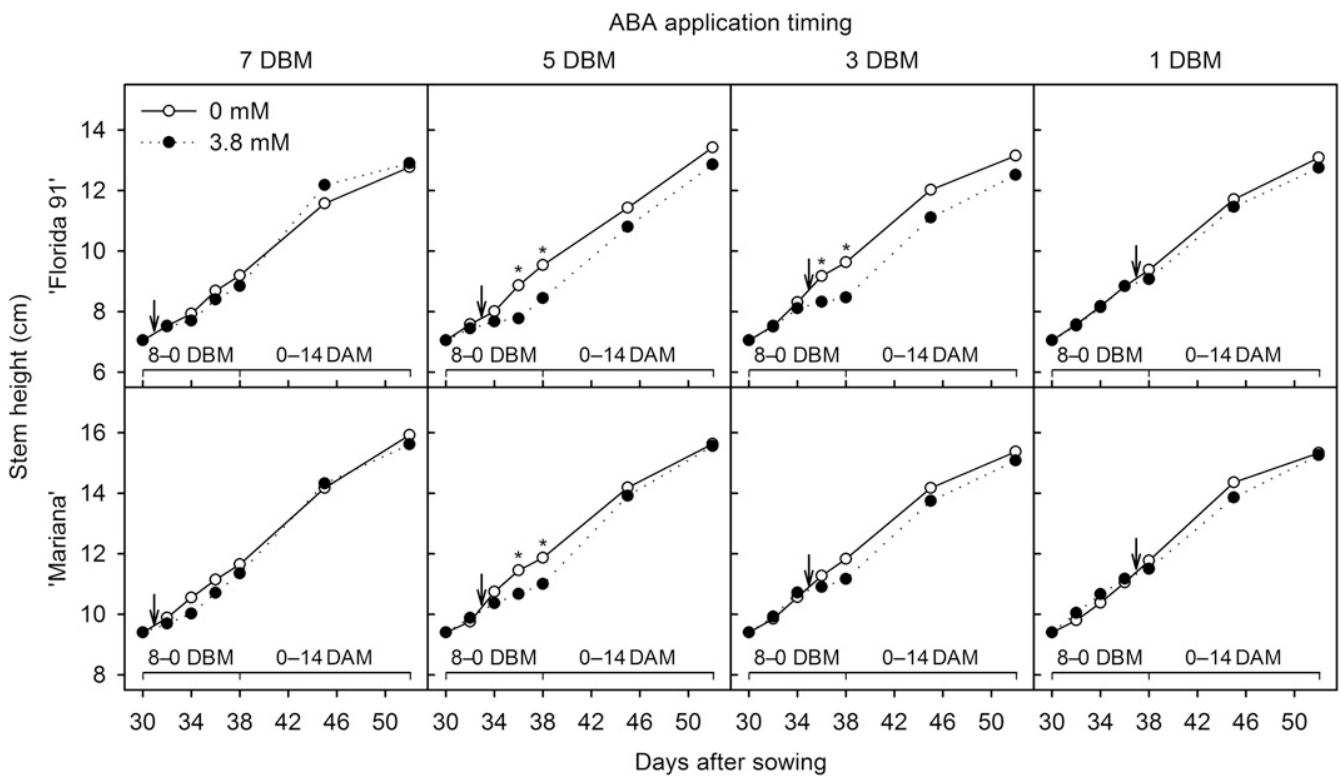

Fig. 1. Stem elongation rate of 'Florida 91' and 'Mariana' tomato seedlings as affected by application timing of abscisic acid (ABA) (Expt. 1: Texas). Arrows indicate ABA spray application events. Data points are means $(n=4)$. Asterisks indicate significant effects of ABA for each application timing (TukeyKramer test, $P<0.05$ ). DBM = days before maturity; DAM = days after maturity. 
7 DAM and slowed down thereafter (Fig. 1). This growth pattern was reflected in RSER, which decreased sharply after 7 DAM (Table 1). In 'Florida 91', stem elongation was inhibited by ABA applied at 5 or 3 DBM (Fig. 1). The magnitude of height suppression was similar for both application timings. Compared with the respective control, suppression in stem elongation by the $5 \mathrm{DBM}$ treatment were $12 \%(1.0 \mathrm{~cm})$ at $2 \mathrm{DBM}$ and $11 \%(1.0 \mathrm{~cm})$ at $0 \mathrm{DBM}$, and those by the 3 DBM treatment were $9 \%(0.9 \mathrm{~cm})$ at $2 \mathrm{DBM}$ and $12 \%(1.2 \mathrm{~cm})$ at 0 DBM. Correspondingly, reductions in RSER from 8 to 0 DBM by the 5 and 3 DBM treatments were $45 \%$ $\left(0.373\right.$ vs. $\left.0.206 \mathrm{~mm} \cdot \mathrm{cm}^{-1} \cdot \mathrm{d}^{-1}\right)$ and $46 \%$ $\left(0.389\right.$ vs. $\left.0.219 \mathrm{~mm} \cdot \mathrm{cm}^{-1} \cdot \mathrm{d}^{-1}\right)$, respectively (Table 1). In 'Mariana', stem elongation was inhibited by ABA only when it was applied at 5 DBM (Fig. 1). Compared with the control, the $5 \mathrm{DBM}$ treatment reduced stem height by $7 \%$ at 2 and 0 DBM $(0.8$ and $0.9 \mathrm{~cm}$, respectively), whereas reducing RSER from 8 to 0 DBM by $31 \%\left(0.285\right.$ vs. $\left.0.197 \mathrm{~mm} \cdot \mathrm{cm}^{-1} \cdot \mathrm{d}^{-1}\right)$. In both cultivars, height suppression by ABA decreased gradually after 0 DBM and became nonsignificant at 7 DAM.

Dry weight and root-to-shoot ratio data discussed below were pooled by ABA concentration, which was the only significant effect during the experiment (Fig. 2A-C). Inhibitory effects of $\mathrm{ABA}$ on shoot dry matter accumulation were rapid and transient in 'Florida 91', decreasing shoot dry weight by $7 \%$ at $0 \mathrm{DBM}$ (184 vs. $171 \mathrm{mg})$, whereas they became gradually significant in 'Mariana', decreasing shoot dry weight by $8 \%$ at 14 DBM (333 vs. 306 mg) (Fig. 2A). By contrast, root dry matter accumulation was unaffected by ABA throughout the experiment in both cultivars (Fig. 2B). Consequently, rootto-shoot ratio of 'Florida 91' increased by $14 \%$ in response to $\mathrm{ABA}$ at $0 \mathrm{DBM}(0.212$ vs. 0.242) (Fig. 2C).

Leaf chlorophyll index in the control decreased gradually during the experiment (Fig. 3). In 'Florida 91', leaf chlorosis, as indicated by reductions in chlorophyll index, was induced by ABA, except when it was applied at 1 DBM. The maximal chlorophyll reductions were $16 \%$ (42.0 vs. 35.4$), 9 \%$ (39.9 vs. 36.3 ), and $15 \%$ (39.1 vs. 33.4$)$ in the 7, 5, and 3 DBM treatments, respectively, all of which occurred $3 \mathrm{~d}$ after ABA treatment. In 'Mariana', only the 7 DBM treatment induced leaf chlorosis, decreasing chlorophyll index by up to $11 \%$ at $4 \mathrm{DBM}$ (40.5 vs. 35.9$)$. In both cultivars, the ABAinduced chlorosis became nonsignificant after 0 DBM, with chlorophyll index gradually recovering to the control level.

ABA and uniconazole effects (Expt. 2). All data discussed below were pooled by each main effect, because they were not significantly affected by the cultivar $\times$ plant growth regulator interaction throughout the experiment. In terms of cultivar effect, stem elongation showed a similar trend as in the Expt. 1 , with 'Mariana' showing higher stem height and shoot dry weight than 'Florida 91' (Tables 2 and 3).

Table 1. RSER of 'Florida 91' and 'Mariana' tomato seedlings as affected by application timing of ABA (Expt. 1: Texas).

\begin{tabular}{|c|c|c|c|c|c|}
\hline \multirow[b]{2}{*}{ Cultivar } & \multirow{2}{*}{$\begin{array}{c}\text { Application } \\
\text { timing (DBM) }\end{array}$} & \multirow[b]{2}{*}{ ABA concn $(\mathrm{mM})$} & \multicolumn{3}{|c|}{$\operatorname{RSER}\left(\mathrm{mm} \cdot \mathrm{cm}^{-1} \cdot \mathrm{d}^{-1}\right)$} \\
\hline & & & $\overline{8-0 \mathrm{DBM}}$ & $0-7$ DAM & $7-14$ DAM \\
\hline \multirow[t]{8}{*}{ Florida 91} & 7 & 0.0 & $0.353 \mathrm{a}^{\mathrm{z}}$ & $0.318 \mathrm{bc}$ & 0.175 \\
\hline & & 3.8 & $0.324 a b$ & $0.444 \mathrm{a}$ & 0.156 \\
\hline & 5 & 0.0 & $0.373 \mathrm{a}$ & $0.263 \mathrm{c}$ & 0.208 \\
\hline & & 3.8 & $0.206 \mathrm{~b}$ & $0.364 \mathrm{abc}$ & 0.195 \\
\hline & 3 & 0.0 & $0.389 \mathrm{a}$ & $0.316 \mathrm{bc}$ & 0.134 \\
\hline & & 3.8 & $0.219 \mathrm{~b}$ & $0.391 \mathrm{ab}$ & 0.156 \\
\hline & 1 & 0.0 & $0.350 \mathrm{a}$ & $0.324 \mathrm{bc}$ & 0.141 \\
\hline & & 3.8 & $0.304 \mathrm{ab}$ & $0.345 \mathrm{abc}$ & 0.127 \\
\hline \multirow[t]{8}{*}{ Mariana } & 7 & 0.0 & $0.261 \mathrm{ab}$ & 0.282 & 0.154 \\
\hline & & 3.8 & $0.237 \mathrm{ab}$ & 0.326 & 0.130 \\
\hline & 5 & 0.0 & $0.285 \mathrm{a}$ & 0.251 & 0.121 \\
\hline & & 3.8 & $0.197 \mathrm{~b}$ & 0.330 & 0.163 \\
\hline & 3 & 0.0 & $0.284 a b$ & 0.254 & 0.114 \\
\hline & & 3.8 & $0.219 \mathrm{ab}$ & 0.296 & 0.143 \\
\hline & 1 & 0.0 & $0.281 \mathrm{ab}$ & 0.282 & 0.096 \\
\hline & & 3.8 & $0.260 \mathrm{ab}$ & 0.270 & 0.158 \\
\hline
\end{tabular}

$\overline{\mathrm{DBM}}=$ days before maturity; $\mathrm{DAM}=$ days after maturity; $\mathrm{RSER}=$ relative stem elongation rate; $\mathrm{ABA}=$ abscisic acid.

${ }^{\mathrm{z}}$ For each cultivar, means $(\mathrm{n}=4)$ in a column with the same letter are not significantly different (TukeyKramer test, $P<0.05)$.

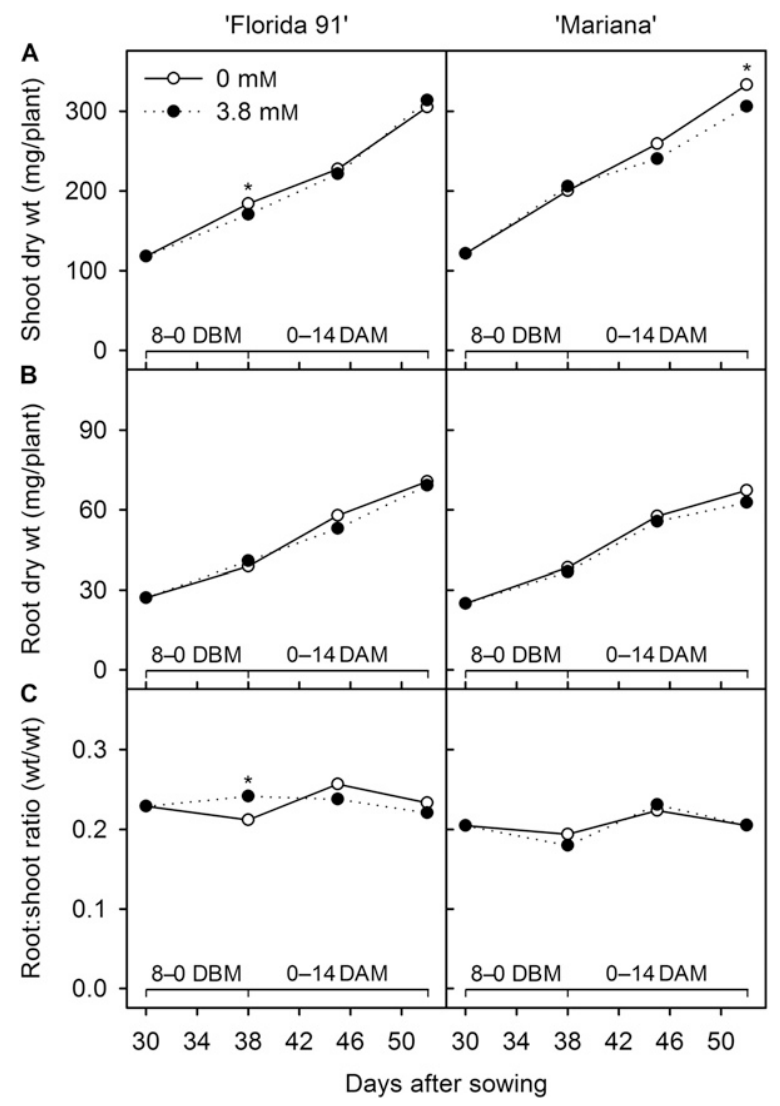

Fig. 2. Dry matter accumulation and partitioning of 'Florida 91' and 'Mariana' tomato seedlings as affected by abscisic acid (ABA) application (Expt. 1: Texas): (A) shoot dry weight, (B) root dry weight, and $(\mathbf{C})$ root-to-shoot ratio. Because the application timing [7, 5, 3, and $1 \mathrm{DBM}$ (days before maturity) $\times \mathrm{ABA}$ concentration $(0$ and $3.8 \mathrm{~mm})$ interaction was nonsignificant, data were pooled by ABA concentration. Data points are group means $(n=4)$. Asterisks indicate significant effects of ABA (Tukey-Kramer test, $P<0.05$ ). DAM $=$ days after maturity.

Stem elongation was not significantly affected by ABA throughout the experiment, although RSER showed a trend of transient inhibition in response to $\mathrm{ABA}(P=0.061$ at 8-0 DBM) (Table 2). By contrast, uniconazole induced a strong, long-term inhibition of stem elongation. Compared with the control and pooled ABA treatments, the unizonazole treatment reduced stem height by $13 \%$ to $14 \%$ at 8 DAM $(10.2-10.3$ vs. $8.9 \mathrm{~cm})$ and $16 \%$ to $17 \%$ at 16 DAM (11.4-11.6 vs. $9.6 \mathrm{~cm})$, whereas decreasing RSER by $61 \%$ to $63 \%$ 


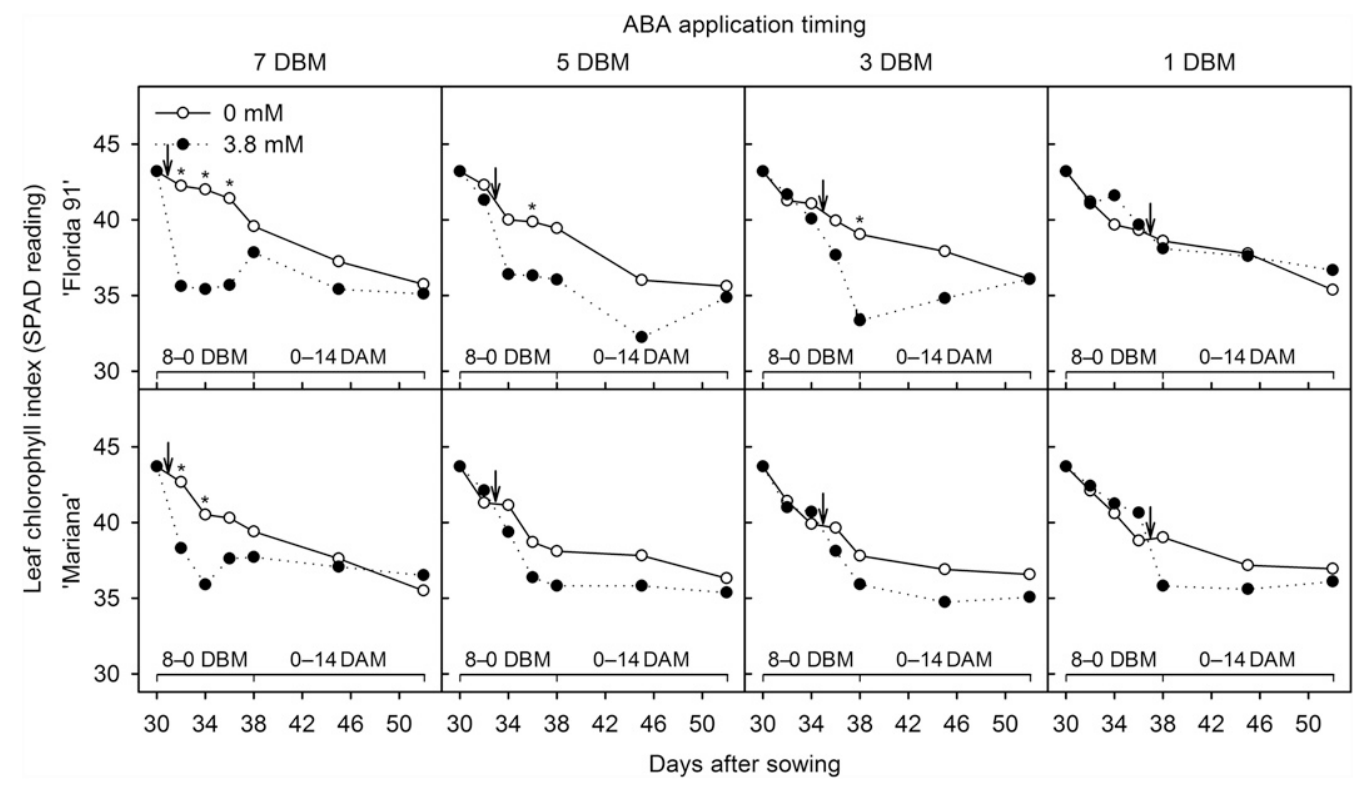

Fig. 3. Leaf chlorophyll index of 'Florida 91' and 'Mariana' tomato seedlings as affected by application timing of abscisic acid (ABA) (Expt. 1: Texas). Arrows indicate ABA spray application events. Data points are means $(\mathrm{n}=4)$. Asterisks indicate significant effects of ABA for each application timing $($ TukeyKramer test, $P<0.05$ ). DBM = days before maturity; DAM = days after maturity.

Table 2. Stem height and RSER of 'Florida 91' and 'Mariana' tomato seedlings as affected by application timing of ABA and uniconazole (Expt. 2: Florida).

\begin{tabular}{|c|c|c|c|c|c|c|c|}
\hline \multirow[b]{3}{*}{ Treatment } & \multicolumn{4}{|c|}{ Stem ht $(\mathrm{cm})$} & \multicolumn{3}{|c|}{$\operatorname{RSER}\left(\mathrm{mm} \cdot \mathrm{cm}^{-1} \cdot \mathrm{d}^{-1}\right)$} \\
\hline & \multicolumn{2}{|c|}{ DBM } & \multicolumn{2}{|c|}{ DAM } & \multirow{2}{*}{$\begin{array}{c}\text { DBM } \\
8-0\end{array}$} & \multicolumn{2}{|c|}{ DAM } \\
\hline & 8 & 0 & 8 & 16 & & $0-8$ & $8-16$ \\
\hline \multicolumn{8}{|l|}{ Cultivar } \\
\hline Florida 91 & 6.7 & $8.3 \mathrm{~b}^{\mathrm{x}}$ & $9.7 \mathrm{~b}$ & $10.8 \mathrm{~b}$ & $0.262 \mathrm{~b}$ & $0.194 \mathrm{~b}$ & $0.129 \mathrm{~b}$ \\
\hline Mariana & 6.7 & $8.6 \mathrm{a}$ & $10.3 \mathrm{a}$ & $11.6 \mathrm{a}$ & $0.301 \mathrm{a}$ & $0.224 \mathrm{a}$ & $0.148 \mathrm{a}$ \\
\hline \multicolumn{8}{|l|}{ Plant growth regulator ${ }^{2}$} \\
\hline Control & 6.7 & 8.6 & $10.3 \mathrm{a}$ & $11.6 \mathrm{a}$ & 0.310 & $0.224 \mathrm{a}$ & $0.150 \mathrm{a}$ \\
\hline ABA (7 DBM) & - & 8.2 & $9.7 \mathrm{a}$ & $10.9 \mathrm{a}$ & 0.246 & $0.206 \mathrm{a}$ & $0.145 \mathrm{a}$ \\
\hline $\mathrm{ABA}(5 \mathrm{DBM})$ & - & 8.4 & $10.2 \mathrm{a}$ & $11.4 \mathrm{a}$ & 0.275 & $0.250 \mathrm{a}$ & $0.136 \mathrm{ab}$ \\
\hline ABA (3 DBM & - & 8.5 & $10.5 \mathrm{a}$ & $11.6 \mathrm{a}$ & 0.289 & $0.255 \mathrm{a}$ & $0.130 \mathrm{ab}$ \\
\hline $\mathrm{ABA}(1 \mathrm{DBM})$ & - & 8.6 & $10.3 \mathrm{a}$ & $11.8 \mathrm{a}$ & 0.310 & $0.232 \mathrm{a}$ & $0.166 \mathrm{a}$ \\
\hline Uniconazole (4 DBM) & - & 8.3 & $8.9 \mathrm{~b}$ & $9.6 \mathrm{~b}$ & 0.258 & $0.086 \mathrm{~b}$ & $0.105 \mathrm{~b}$ \\
\hline Orthogonal contrast ${ }^{\mathrm{y}}$ & \multicolumn{7}{|c|}{$P$ value } \\
\hline Control vs. ABA & - & 0.158 & 0.596 & 0.531 & 0.061 & 0.385 & 0.560 \\
\hline Uniconazole vs. ABA & - & 0.086 & 0.000 & 0.000 & 0.167 & 0.000 & 0.000 \\
\hline
\end{tabular}

$\mathrm{DBM}=$ days before maturity; DAM = days after maturity; RSER = relative stem elongation rate; $\mathrm{ABA}=$ abscisic acid.

${ }^{\mathrm{z}}$ Spray treatments were as follows: no spray control, $3.8 \mathrm{~mm} \mathrm{ABA}$ at $7,5,3$, or $1 \mathrm{DBM}$, and $34 \mu \mathrm{M}$ uniconazole at 4 DBM. Spray volume was $0.2 \mathrm{~L} \cdot \mathrm{m}^{-2}(0.24 \mathrm{~mL} / \mathrm{plant})$.

${ }^{\mathrm{y}}$ Orthogonal contrasts tested two hypotheses: control vs. all ABA treatments (control vs. ABA) and uniconazole vs. all ABA treatments (uniconazole vs. ABA).

${ }^{\mathrm{x}}$ For each main effect, means $(\mathrm{n}=4)$ in a column with the same letter are not significantly different (TukeyKramer, $P<0.05)$.

at $8 \operatorname{DAM}\left(0.224-0.236\right.$ vs. $\left.0.086 \mathrm{~mm} \cdot \mathrm{cm}^{-1} \cdot \mathrm{d}^{-1}\right)$ and $27 \%$ to $30 \%$ at 16 DAM ( $0.144-0.150$ vs. $\left.0.105 \mathrm{~mm} \cdot \mathrm{cm}^{-1} \cdot \mathrm{d}^{-1}\right)$.

Shoot dry matter accumulation was inhibited by ABA applied at 7 and 5 DBM (Table 3). Compared with the control, shoot dry weight reductions by the $7 \mathrm{DBM}$ treatment were $28 \%$ at 0 DBM (150 vs. $108 \mathrm{mg}$ ) and $22 \%$ at 8 DAM (245 vs. $192 \mathrm{mg}$ ), and those by the $5 \mathrm{DBM}$ treatment were $15 \%$ at both 0 DBM (150 vs. $128 \mathrm{mg}$ ) and 8 DAM ( $245 \mathrm{vs} .209 \mathrm{mg}$ ). The uniconazole treatment had no effect on shoot dry matter accumulation. As a result, the pooled ABA treatments showed shoot dry weight reductions of similar magnitude compared with the control and uniconazole treatment.
Root dry matter accumulation was transiently inhibited by ABA applied at 7 DBM (Table 3). At 0 DBM, the 7 DBM treatment reduced shoot dry weight by $21 \%$ compared with the control (41 vs. $32 \mathrm{mg}$ ). Although other ABA treatments were nonsignificant by multiple comparisons, the pooled ABA treatments also had significantly lower root dry weight than the control (41 vs. $37 \mathrm{mg}$ ). These reductions became smaller and were nonsignificant at 8 DAM. By contrast, the uniconazole treatment maintained $9 \%$ to $10 \%$ higher root dry weight than the pooled ABA treatments until 8 DAM.

Dry matter partitioning to roots increased in response to ABA at 8 DAM because of relatively stronger inhibition in shoot growth
(Table 3). The increase in root-to-shoot ratio by the pooled ABA treatments was $8 \%$ compared with the control $(0.223$ vs. 0.241$)$. The similar effect was observed in the uniconazole treatment, with a $13 \%$ increase in rootto-shoot ratio compared with the control at 8 DAM (0.223 vs. 0.252).

\section{Discussion}

Differential growth modulations by $A B A$ and uniconazole. Spray applications of $3.8 \mathrm{~mm}$ ABA between 7 and 1 DBM and $34 \mu \mathrm{M}$ uniconazole at $4 \mathrm{DBM}$ were both effective in slowing excessive growth of tomato transplants, but they induced different morphological changes. First, suppression of stem elongation by ABA was reversible by 7 DAM (Fig. 1), whereas that by uniconazole lasted for $20 \mathrm{~d}$ or until 16 DAM with up to $17 \%$ reduction in stem length (Table 2). Second, shoot dry matter accumulation was inhibited only by ABA (Fig. 2A; Table 3). The overall effect of ABA was a delay in excessive shoot growth, whereas uniconazole produced more compact transplants without affecting leaf and root growth. Similar findings were observed in our previous study using pepper seedlings with the same experiment approach (Agehara and Leskovar, 2015).

To maintain the desirable shoot size of transplants and prolong their marketable period, an overall growth delay must be induced shortly before the anticipated maturity stage to a predictable and manageable extent. In this study, ABA reduced shoot biomass at the maturity stage mainly by inhibiting leaf expansion (Fig. 2A; Table 3) and the ABA-induced growth suppression was significant up to 8 DAM (Table 3). By contrast, the inhibitory effects of ABA on root growth were relatively small (Fig. 2B; 
Table 3. Dry matter accumulation and partitioning of 'Florida 91 ' and 'Mariana' tomato seedlings as affected by application timing of ABA and uniconazole (Expt. 2: Florida).

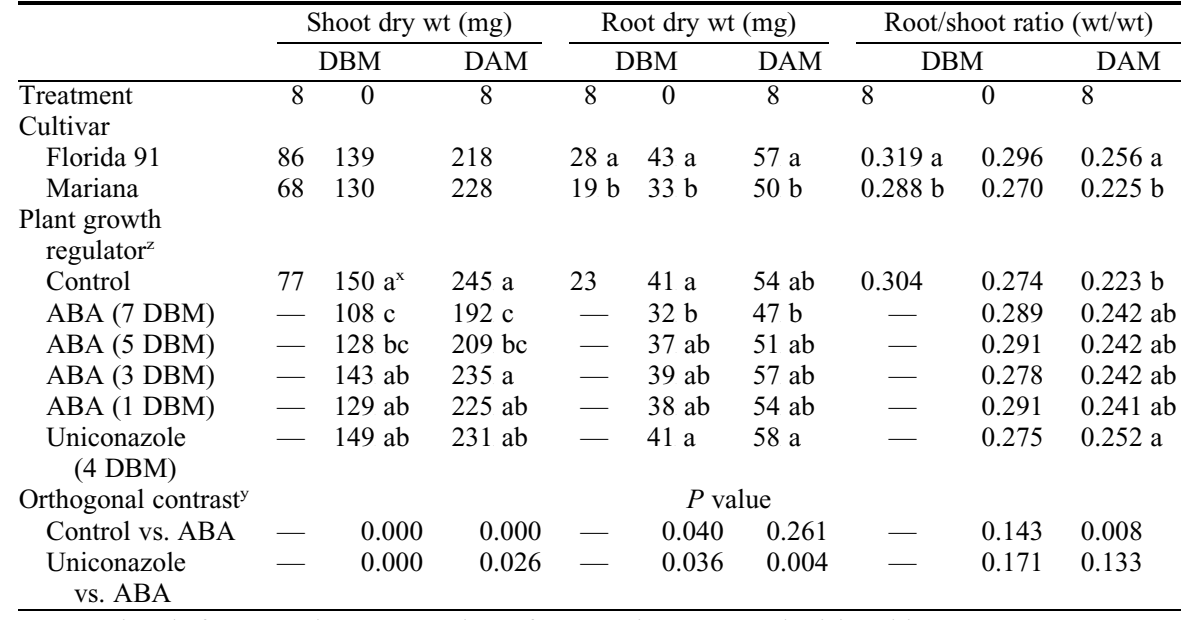

$\mathrm{DBM}=$ days before maturity; $\mathrm{DAM}=$ days after maturity; $\mathrm{ABA}=$ abscisic acid.

${ }^{\mathrm{z}}$ Spray treatments were as follows: no spray control, $3.8 \mathrm{~mm} \mathrm{ABA}$ at $7,5,3$, or $1 \mathrm{DBM}$, and $34 \mu \mathrm{M}$ uniconazole at 4 DBM. Spray volume was $0.2 \mathrm{~L} \cdot \mathrm{m}^{-2}(0.24 \mathrm{~mL} / \mathrm{plant})$.

${ }^{\mathrm{y}}$ Orthogonal contrasts tested two hypotheses: control vs. all ABA treatments (control vs. ABA) and uniconazole vs. all ABA treatments (uniconazole vs. ABA).

${ }^{\mathrm{x}}$ For each main effect, means $(\mathrm{n}=4)$ in a column with the same letter are not significantly different (TukeyKramer, $P<0.05)$.

Table 3). The resulting increase in root-toshoot ratio at the maturity stage or 8 DAM is a preferable characteristic of high-quality vegetable transplants (Vavrina, 2002). Sufficient root development by the time of transplanting is important to facilitate pulling of transplants from trays (Vavrina, 2002). Increasing root-to-shoot ratio may also minimize transplant shock by preventing excess transpiration relative to water uptake (Agehara and Leskovar, 2012). It is reported that ABA can restrict plant growth directly by inhibiting leaf expansion (Alves and Setter, 2000; Bacon et al., 1998; He and Cramer, 1996), or indirectly by inducing stomatal closure, which in turn inhibits photosynthesis and limits the supply of assimilates for dry matter production (Amthor, 2007; Lawlor, 2002). Importantly, the observed ABA-induced growth reductions were moderate and mostly reversible. These findings were also observed in our previous study using bell pepper transplants (Agehara and Leskovar, 2015).

Another important feature of successful growth retardants is to induce only transient growth inhibition to minimize negative side effects on postplanting growth in the field. In this study, height suppression by ABA was completely reversible by 7 DAM (Fig. 1; Tables 1 and 2). Shoot biomass also showed recoveries from the ABA-growth inhibition, although it did not recover to the control level by the end of the experiment (Table 3 ). The biosynthesis of endogenous ABA is stimulated by water stress to induce adaptive stress responses, such as stomatal closure and suppression of leaf expansion, which are generally transient growth suppression (Taiz and Zeiger, 2010). The magnitude and duration of these stress responses by exogenous ABA are concentration dependent (Agehara and Leskovar, 2012). In muskmelon seedlings, we have reported that $7.6 \mathrm{~mm}$ exogenous ABA inhibited net $\mathrm{CO}_{2}$ assimilation rate by 95\% within $24 \mathrm{~h}$ and caused excessive growth inhibition (Agehara and Leskovar, 2012). When exogenous ABA was applied before transplanting at 1.9 to $3.8 \mathrm{~mm}$, we have also reported that $\mathrm{ABA}$-induced growth inhibition was transient with no negative impact on yield in other crops including bell pepper, jalapeño, and watermelon (Agehara and Leskovar, 2014a, 2014b). The transient effects of ABA are due likely to oxidation or conjugation that rapidly inactivates $\mathrm{ABA}$ in plant tissue (Davies and Jones, 1991). Conversely, synthetic ABA analogs are known to have long-term effects because of their high chemical stability (Abrams et al., 1997). For example, growth inhibition in tomato seedlings by $50-100 \mu \mathrm{M} A B A$ analogs $\left(8^{\prime}\right.$-methylene ABA methyl ester and $8^{\prime}$-acetylene ABA methyl ester) was strong and not recovered at the end of a 9-d evaluation period, with up to a $33 \%$ reduction in shoot biomass compared with the control (Sharma et al., 2006b). In field trials with tomato and pumpkin (Cucurbita pepo L.), pretransplanting application of $8^{\prime}$ acetylene ABA methyl ester at $100 \mu \mathrm{M}$ reduced transplant shock but slowed subsequent growth, resulting in limited fruit set (Sharma et al., 2006a). Therefore, as a growth retardant, the easily degradable natural ABA appears to be more suitable than its analogs and uniconazole.

In contrast to ABA, uniconazole had a long-term inhibitory effect on stem elongation, which took more than $20 \mathrm{~d}$ to be reversible (Table 2). In our previous study, bell pepper transplants took more than $30 \mathrm{~d}$ to recover from the growth inhibition by uniconazole (Agehara and Leskovar, 2015). Similar long-term height control effects of uniconazole are reported in many ornamental species (Blanchard and Runkle, 2007; Currey et al., 2012; Gibson and Whipker, 2001, 2003). Uniconazole inhibits the synthesis of gibberellins, which are involved in both cell division and expansion (Taiz and Zeiger, 2010). This mode of action appears to be more effective in height suppression than the ABA-induced growth inhibition described earlier. On the other hand, uniconazole had no significant effect on shoot and root dry matter accumulation. This observation is interesting because gibberellin synthesis is particularly active in young developing leaves and gibberellins promote leaf expansion by stimulating cell elongation (Hedden and Kamiya, 1997; Van Volkenburgh, 1999). A possible explanation may be that stem elongation is simply more sensitive to gibberellins than leaf expansion. In fact, the most pronounced effect of exogenous gibberellins is often the stimulation of internode elongation (Taiz and Zeiger, 2010). The tissue-specific growth inhibition by uniconazole may be more beneficial for height control of vegetable transplants than as a growth holding strategy.

Negative side effects of $A B A$. Leaf chlorosis is often reported as a negative side effect of ABA application in various crops (Agehara and Leskovar, 2012; Kim and van Iersel, 2011; Waterland et al., 2010). The ABAinduced chlorosis can be attributed to the senescing effects of ABA, resulting from the gene expression of hydrolytic enzymes involved in chlorophyll breakdown and cell wall degradation (Mishra et al., 2008; Taylor et al., 1991; Tucker et al., 1991; Weaver et al., 1998) or the stimulation of ethylene production (Gepstein and Thimann, 1981). This study also demonstrated that $3.8 \mathrm{~mm}$ ABA can induce leaf chlorosis in tomato seedlings, with maximal chlorophyll loss of $12 \%$ based on the leaf chlorophyll index (Fig. 3). However, it is important to note that the ABA-induced chlorosis is transient and is reversible within $7 \mathrm{~d}$, mostly before shipping. Similar findings were observed in our previous study using bell pepper seedlings with the same experiment approach (Agehara and Leskovar, 2015).

Practical implications. To prolong the marketable period of vegetable transplants, an overall growth delay must be induced shortly before the anticipated maturity stage without negative side effects on transplant quality and postplanting performance. At present, uniconazole registered as Sumagic is used primarily for height control of vegetable transplants. In this study, the primary effect of uniconazole applied to tomato transplants near the maturity stage was limited to the long-term height suppression, suggesting that it is more beneficial for height control than as a growth holding agent. This conclusion supports the current recommendation for Sumagic applications described in the supplemental label.

By contrast, single spray application of $3.8 \mathrm{~mm}$ ABA shortly before the anticipated maturity stage appears to be an effective growth holding strategy for tomato transplants. Both growth suppression and leaf 
chlorosis were induced more severely when ABA was applied 7 to $5 \mathrm{DBM}$ than 3 to 1 DBM, indicating the age-dependent sensitivity of tomato seedlings to exogenous ABA. Although leaf chlorosis can result in the visual quality loss of transplants, the ABAinduced leaf chlorosis is only transient and is mostly reversible before shipping. Therefore, ABA should be applied 7 to 5 DBM especially when the delay in shipping is expected to be more than 1 week. Importantly, this conclusion is supported by data collected under commercial nursery conditions. Furthermore, minimal location- and cultivarspecific effects of this strategy suggest that it may be easily implemented for commercial use without extensive optimization of application methods.

In addition to prolonged transplant marketability, other beneficial consequences can be expected for this strategy. For example, suppression of excessive shoot growth can reduce maintenance costs during the extended growth period (Sharma et al., 2006b). It can also minimize damage during handling, especially when transplants are pulled from trays and packed in boxes at high density for shipment (Cantliffe, 1993). Furthermore, preferential biomass partitioning in roots may aid in improving stand establishment and subsequent field growth (Agehara and Leskovar, 2012; Garner and Björkman, 1999; Sharma et al., 2006a).

\section{Literature Cited}

Abrams, S.R., P.A. Rose, A.J. Cutler, J.J. Balsevich, B. Lei, and M.K. Walker-Simmons. 1997. $8^{\prime}$-Methylene abscisic acid: An effective and persistent analog of abscisic acid. Plant Physiol. 114:89-97.

Agehara, S. and D.I. Leskovar. 2012. Characterizing concentration effects of exogenous abscisic acid on gas exchange, water relations, and growth of muskmelon seedlings during water stress and rehydration. J. Amer. Soc. Hort. Sci. 137:400-410.

Agehara, S. and D.I. Leskovar. 2014a. Age-dependent effectiveness of exogenous abscisic acid in height control of bell pepper and jalapeño transplants. Sci. Hort. 175:193-200.

Agehara, S. and D.I. Leskovar. 2014b. Growth reductions by exogenous abscisic acid limit the benefit of height control in diploid and triploid watermelon transplants. HortScience 49:465471.

Agehara, S. and D.I. Leskovar. 2015. Growth suppression by exogenous abscisic acid and uniconazole for prolonged marketability of bell pepper transplants in commercial conditions. Sci. Hort. 194:118-125.

Alves, A.A.C. and T.L. Setter. 2000. Response of cassava to water deficit: Leaf area growth and abscisic acid. Crop Sci. 40:131-137.
Amthor, J.S. 2007. Improving photosynthesis and yield potential, p. 27-58. In: P. Ranalli (ed.) Improvement of crop plants for industrial end uses. Springer, Dordrecht, The Netherlands.

Bacon, M.A., S. Wilkinson, and W.J. Davies. 1998. pH-regulated leaf cell expansion in droughted plants is abscisic acid dependent. Plant Physiol. 118:1507-1515.

Biai, C.J., J.G. Garzon, J.A. Osborne, J.R. Schultheis, R.J. Gehl, and C.C. Gunter. 2011. Height control in three pepper types treated with drenchapplied abscisic acid. HortScience 46:12651269.

Blanchard, M.G. and E.S. Runkle. 2007. Dipping bedding plant liners in paclobutrazol or uniconazole inhibits subsequent stem extension. HortTechnology 17:178-182.

Cantliffe, D.J. 1993. Pre- and postharvest practices for improved vegetable transplant quality. HortTechnology 3:415-418.

Currey, C.J. and R.G. Lopez. 2010. Applying plant growth retardants for height control. Purdue Ext. HO-248-W.

Currey, C.J., R.G. Lopez, B.A. Krug, I. McCall, and B.E. Whipker. 2012. Substrate drenches containing flurprimidol suppress height of 'Nellie White' easter lilies. HortTechnology 22:164-168

Davies, W.J. and H.G. Jones. 1991. Abscisic acid: Physiology and biochemistry. BIOS Scientific Publishers, Oxford, UK.

Garner, L.C. and T. Björkman. 1996. Mechanical conditioning for controlling excessive elongation in tomato transplants: Sensitivity to dose, frequency, and timing of brushing. J. Amer. Soc. Hort. Sci. 121:894-900.

Garner, L.C. and T. Björkman. 1999. Mechanical conditioning of tomato seedlings improves transplant quality without deleterious effects on field performance. HortScience 34:848851

Gepstein, S. and K.V. Thimann. 1981. The role of ethylene in the senescence of oat leaves. Plant Physiol. 68:349-354.

Gibson, J.L. and B.E. Whipker. 2001. Ornamental cabbage and kale growth responses to daminozide, paclobutrazol, and uniconazole. HortTechnology 11:226-230.

Gibson, J.L. and B.E. Whipker. 2003. Efficacy of plant growth regulators on the growth of vigorous Osteospermum cultivars. HortTechnology 13:132-135.

He, T. and G.R. Cramer. 1996. Abscisic acid concentrations are correlated with leaf area reductions in two salt-stressed rapid-cycling brassica species. Plant Soil 179:25-33.

Hedden, P. and Y. Kamiya. 1997. Gibberellin biosynthesis: Enzymes, genes and their regulation. Annu. Rev. Plant Physiol. Plant Mol. Biol. 48:431-460.

Kim, J. and M.W. van Iersel. 2011. Abscisic acid drenches can reduce water use and extend shelf life of Salvia splendens. Sci. Hort. 127:420-423.

Latimer, J.G. and C.A. Mitchell. 1988. Effects of mechanical stress or abscisic acid on growth, water status and leaf abscisic acid content of eggplant seedlings. Sci. Hort. 36:37-46.
Lawlor, D.W. 2002. Limitation to photosynthesis in water-stressed leaves: Stomata vs. metabolism and the role of ATP. Ann. Bot. (Lond.) 89:871-885.

Leskovar, D.I. and D.J. Cantliffe. 1992. Pepper seedling growth response to drought stress and exogenous abscisic acid. J. Amer. Soc. Hort. Sci. 117:389-393.

Marr, C.W. and M. Jirak. 1990. Holding tomato transplants in plug trays. HortScience 25:173176.

Mishra, A., S. Khare, P.K. Trivedi, and P. Nath. 2008. Effect of ethylene, 1-MCP, ABA and IAA on break strength, cellulase and polygalacturonase activities during cotton leaf abscission. S. Afr. J. Bot. 74:282-287.

Nishizawa, T. and K. Saito. 1998. Effects of rooting volume restriction on the growth and carbohydrate concentration in tomato plants. J. Amer. Soc. Hort. Sci. 123:581-585.

Rademacher, W. 2000. Growth retardants: Effects on gibberellin biosynthesis and other metabolic pathways. Annu. Rev. Plant Biol. 51:501-531.

Sharma, N., S.R. Abrams, and D.R. Waterer. 2006a. Abscisic acid analogs reduce transplant shock in tomato seedlings. J. Veg. Sci. 11:4156.

Sharma, N., D.R. Waterer, and S.R. Abrams 2006b. Evaluation of abscisic acid analogs as holding agents for bedding plant seedlings. HortTechnology 16:71-77.

Shaw, L.N. 1993. Changes needed to facilitate automatic field transplanting. HortTechnology 3:418-420.

Taiz, L. and E. Zeiger. 2010. Plant physiology. 5th ed. Sinauer Assoc., Sunderland, MA.

Taylor, J.E., G.A. Tucker, Y. Lasslett, C.J.S. Smith, C.M. Arnold, C.F. Watson, W. Schuch, D. Grierson, and J.A. Roberts. 1991. Polygalacturonase expression during leaf abscission of normal and transgenic tomato plants. Planta 183:133-138

Tucker, M.L., S.L. Baird, and R. Sexton. 1991. Bean leaf abscission: Tissue-specific accumulation of a cellulase mRNA. Planta 186:52-57.

Umezawa, T. 2011. Systems biology approaches to abscisic acid signaling. J. Plant Res. 124:539548.

Van Volkenburgh, E. 1999. Leaf expansion: An integrating plant behaviour. Plant Cell Environ. 22:1463-1473.

Vavrina, C.S. 2002. An introduction to the production of containerized vegetable transplants. Fla. Coop. Ext. Serv. HS849.

Waterland, N.L., J.J. Finer, and M.L. Jones. 2010. Benzyladenine and gibberellic acid application prevents abscisic acid-induced leaf chlorosis in pansy and viola. HortScience 45:925-933.

Weaver, L.M., S. Gan, B. Quirino, and R.M. Amasino. 1998. A comparison of the expression patterns of several senescence-associated genes in response to stress and hormone treatment. Plant Mol. Biol. 37:455-469.

Yamazaki, H., T. Nishijima, and M. Koshioka 1995. Effects of $(+)$-s-abscisic acid on the quality of stored cucumber and tomato seedlings. HortScience 30:80-82. 